\title{
The renewability indicator and cumulative degree of perfection for gamboeng tea; part.1, exergy calculation of fresh tea leaf
}

\author{
Teuku Beuna Bardant ${ }^{1}$, Muthia Syafika $\mathrm{Haq}^{2}$, Arief Ameir Rahman Setiawan ${ }^{1}$, Sugeng \\ Harianto $^{2}$, Joko Waluyo ${ }^{1}$, Adhi Irianto Mastur ${ }^{2}$, Annisa Dieni Lestari ${ }^{1}$, Sujarwo ${ }^{1}$, Anny \\ Sulaswatty $^{1}$, and Edi Iswanto Wiloso ${ }^{1}$ \\ ${ }^{1}$ Research Center for Chemistry LIPI, Kawasan PUSPIPTEK Serpong Tangerang Banten \\ Indonesia \\ ${ }^{2}$ Research Institute for Tea and Cinchona, Desa Mekarsari, Pasir Jambu Kabupaten Bandung, \\ Indonesia
}

\begin{abstract}
Renewability Indicator (RI) and Cumulative Degree of Perfection (CDP) are employed as tools to assess sustainability of Gamboeng Tea. The assessment then compared with black tea process in Black Sea Region in Turkey from the previous study. Exergy analysis for Gamboeng tea was decribed in two part of articles. This first part was desribing the energy and exergy calculation for producing fresh tea leaf in Gamboeng tea plantation. The energy and exergy utilization for black sea fresh tea leaves was calculated to be $807.83 \mathrm{MJ} / \mathrm{t}$ of fresh leaf, $273.43 \mathrm{MJ} / \mathrm{t}$ of fresh leaf, respectively. For the Gamboeng green tea, the energy and exergy utilization were $1496.38 \mathrm{MJ} / \mathrm{t}$ of fresh leaf and $821.86 \mathrm{MJ} / \mathrm{t}$ of fresh leaf, respectively. The second part desribed cooperation of wood pellet with ambient-adapting controller uin tea factorywas a contribution from Gamboeng Tea for achieving Sustainable Development Goal which is affordable and clean energy and also an applicable climate action.
\end{abstract}

\section{Introduction}

The necessity of producing food in both effectively and efficiently will become even more profound because the continuation of unsustainable processing practices will contribute to the irreversible depletion of the Earth's natural resources. Several methodologies have been proposed in order to assess and improve the sustainability of various processes and products such as mass flow analysis (MFA; also known as material throughput analysis), energy analysis (EA), life cycle assessment (LCA), cradle-to-cradle design (C2C), and pinch analysis among others [1-5].

Energy is the most common term used by the food industry to understand process and system performance or efficiency. In transformation from one energy form to another, part of its initial quality is destroyed (irreversibly lost), leading to a lower, degraded quality [6].

*Corresponding author: qaismajnun@gmail.com 
The concept of energy quality has been described by Van Gool as the possibility of energy exchange between a donating and an accepting stream [7]. Cornelissen defined this possibility as the "maximum work potential of a material or of a form of energy in relation to its environment," and also known as available work or exergy, a term which was originally introduced by Rant $[8,9]$.

Now, consensus among many authors from different scientific fields develops exergy analysis (ExA) as an objective methodology for assessing the efficiency and hence sustainability of processes and systems. ExA was prefered because it is based on the first and the second law of thermodynamics, considering both the quantity and the quality of material and energy streams simultaneously without having to resort to subjective weighing factors $[6,10-18]$. The advantages of using ExA over other assessment methods have been discussed in detail by various authors, e.g. Gong and Wall and Dincer and Rosen [18,19]. The basic principles, the general definitions, and the differences between energy and exergy have been discussed [20, 21].

Most food process-related publications using ExA focus on drying technologies (66\%), followed by food chains having wider boundaries (10\%) and heating/pasteurization processes $(6 \%)$ [22]. Conducting ExA for analyzing drying performance firstly introduced in Indonesia was for analyzing application of solar thermal storage [23]. Tea is the second most consumed non-alcoholic drink, after water, in the world [24,25] which the main process was drying. In this present study, Gamboeng green tea will be evaluated by using Exergy analysis (ExA) and the results will be presented as Cumulative Degree of Perfection (CDP) and the renewability indicator (RI). The cumulative degree of perfection (CDP) is defined as the ratio of the exergy of the products to the sum of the exergies of the input materials and non-renewable fuels [26]. According to Shao and Chen, renewability assessment has two implications: calculation input/output ratio of a specific renewable resource based on benefit analysis or to investigate the sustainability of a concerned system by identifying the renewable resources component from its total historical resources [27].

\section{Methodology}

To compare the results of analysis, the functional unit for Gamboeng green tea and Black Sea black tea, the functional units was one ton of products. Information about transportation requirement for Gamboeng tea were collected by direct observation and measurement from tea plantation and tea factory belong to Research Institute for Tea and Cinchona in Desa Mekarsari Kecamatan Pasir jambu Kabupaten Bandung. The tea factory was operated in batch for $14-20$ hour per batch operated by 46 employees. The average distances that the tea was transported were reported as $50 \mathrm{~km}$ between fields and factory $30 \mathrm{~km}$ from factory to the consumer. The trucks are considered to be making two-way trip, since they are empty on the way back.

Energy utilization by equipment of each green tea production steps are also obtained from interviewed with the tea factory manager. Calculations are based on theoretical considerations by using Gamboeng environmental climatology data as basic of the calculation. The ambient air condition as basic for calculation were the average measured value from 15 September 2018 to 15 October 2018 which were $65 \%$ relative humidity and $30.5^{\circ} \mathrm{C}$ of air ambient temperature. The climate data was collected from Automatic Weather Station (AWS) that placed in Gamboneg. Moisture content of tea leaf along the process was determined based the weight loss at $103{ }^{\circ} \mathrm{C}$ referring to SNI 3945:2016. The data was collected between $8^{\text {th }}$ of October to $12^{\text {th }}$ of October 2018 and the mean value was used in the calculation. LPG consumption for calculation was obtained from the monthly record of the factory manager. 


\section{Results and discussion}

\subsection{Green tea production process}

First challenging step for conducting exergy assessment was calculating exergy of tea leaves. Estimation of the energy and exergy utilization and the carbon dioxide emission associated with the agriculture of tea leaves are given in Table.1. Calculation for Gamboeng green tea was using literature source that similar with those used by Pelvan and Ozilgen for Black sea tea except for energy associated nitrogen chemical fertilizer [29].

Table 1. estimation of energy and exergy utilization associated with the agriculture of tea leaves.

\begin{tabular}{|c|c|c|c|c|c|c|c|c|}
\hline \multirow[b]{2}{*}{ parameters (unit) } & \multicolumn{4}{|c|}{ black sea tea } & \multicolumn{4}{|c|}{ Gamboeng tea } \\
\hline & \multicolumn{3}{|c|}{ data } & ref & \multicolumn{3}{|c|}{ data } & ref \\
\hline \multicolumn{9}{|c|}{ general information } \\
\hline tea productivity (ton/Ha) & \multicolumn{3}{|c|}{4.10} & \multirow{4}{*}{ [29] } & \multicolumn{3}{|c|}{1.2} & \multirow{4}{*}{$\begin{array}{l}\text { survey } \\
\text { in this } \\
\text { study }\end{array}$} \\
\hline $\begin{array}{l}\text { required fresh leaf for } 1 \text { ton } \\
\text { of product (ton) }\end{array}$ & \multicolumn{3}{|c|}{3.88} & & \multicolumn{3}{|c|}{3.32} & \\
\hline \multirow[b]{2}{*}{ fertilizer utilization $(\mathrm{kg} / \mathrm{Ha})$} & $\mathrm{N}$ & $\mathrm{P}$ & $\mathrm{K}$ & & $\mathrm{N}$ & $\mathrm{P}$ & $\mathrm{K}$ & \\
\hline & 30 & 25 & 30 & & 30 & 14 & 12 & \\
\hline \multicolumn{9}{|c|}{ energy utilization for chemical fertilizer application } \\
\hline $\begin{array}{l}\text { energy associated with } \\
\text { chemical fertilizer }(\mathrm{Mj} / \mathrm{kg})\end{array}$ & 78.2 & 17.5 & 13.8 & [32] & $40^{*}$ & 25.20 & 8.28 & {$[31 *, 32]$} \\
\hline $\begin{array}{l}\text { energy utilization assoctd } \\
\text { with fertilizer perHa }(\mathrm{Mj} / \mathrm{Ha})\end{array}$ & 2346 & 437.5 & 414 & \multirow{3}{*}{ [29] } & 1,200 & 352.8 & 99.4 & \multirow{3}{*}{$\begin{array}{c}\text { Calcula } \\
\text { ted in } \\
\text { this } \\
\text { study }\end{array}$} \\
\hline $\begin{array}{l}\text { energy utilization assoctd with } \\
\text { fertilizer perton fresh leaf }(\mathrm{Mj} / \mathrm{t})\end{array}$ & 572.5 & 106.7 & 101 & & 1,000 & 294 & 82.8 & \\
\hline $\begin{array}{l}\text { total energy utilization per } \\
\text { ton of fresh tea leaf (MJ/ton) }\end{array}$ & \multicolumn{3}{|c|}{780.37} & & \multicolumn{3}{|c|}{1376.78} & \\
\hline \multicolumn{9}{|c|}{ Cumulative exergy Consumption (CExC) for chemical fertilizer application } \\
\hline $\begin{array}{l}\text { exergy associated with } \\
\text { chemical fertilizer }(\mathrm{Mj} / \mathrm{kg})\end{array}$ & 23.02 & 7.50 & 4.60 & {$[33,34]$} & 23.02 & 7.50 & 4.60 & {$[33,34]$} \\
\hline $\begin{array}{l}\text { exergy utilization assoctd with } \\
\text { fertilizer perHa }(\mathrm{Mj} / \mathrm{Ha})\end{array}$ & 690.8 & 187.5 & 138. & \multirow{3}{*}{ [29] } & 690.8 & 105 & 55.2 & \multirow{3}{*}{$\begin{array}{c}\text { Calcula } \\
\text { ted in } \\
\text { this } \\
\text { study }\end{array}$} \\
\hline $\begin{array}{l}\text { exergy utilization assoctd with } \\
\text { fertilizer perton fresh leaf }(\mathrm{Mj} / \mathrm{t})\end{array}$ & 168.6 & 45.76 & 33.7 & & 575.6 & 87.5 & 46 & \\
\hline $\begin{array}{l}\text { total exergy utilization per } \\
\text { ton of fresh tea leaf (MJ/ton) }\end{array}$ & \multicolumn{3}{|c|}{248.02} & & \multicolumn{3}{|c|}{709.12} & \\
\hline \multicolumn{9}{|c|}{ general information of transportation } \\
\hline shipment capacity (ton) & & 10 & & \multirow{3}{*}{ [29] } & \multicolumn{3}{|c|}{4} & \multirow{3}{*}{$\begin{array}{l}\text { survey } \\
\text { in this } \\
\text { study }\end{array}$} \\
\hline consumption $(\mathrm{L} / \mathrm{km})$ & \multicolumn{3}{|c|}{0.287} & & & 0.2 & & \\
\hline distance $(\mathrm{km})$ & & 20 & & & & 50 & & \\
\hline diesel oil density $(\mathrm{kg} / \mathrm{L})$ & & 0.832 & & {$[35]$} & & 0.832 & & [35] \\
\hline & nerg & utilizat & for $\mathrm{t}$ & ansportat & & & & \\
\hline energy equivalen $(\mathrm{Mj} / \mathrm{kg})$ & & 57.5 & & {$[35]$} & & 57.5 & & [35] \\
\hline total energy for transport $(\mathrm{MJ})$ & & 274.60 & & & & 478.4 & & this \\
\hline energy for transport $(\mathrm{MJ} / \mathrm{t})$ & & 27.46 & & {$[29]$} & & 119.6 & & study \\
\hline & exergy & utilizati & $\mathrm{n}$ for $\mathrm{t}$ & ansportat & & & & \\
\hline exergy equivalen $(\mathrm{Mj} / \mathrm{kg})$ & & 53.2 & & [26] & & 54.2 & & [26] \\
\hline total exergy for transport (MJ) & & 254.07 & & & & 450.94 & & \\
\hline Exergy for transport $(\mathrm{MJ} / \mathrm{t})$ & & 25.41 & & [29] & & 112.74 & & study \\
\hline & & SUI & IMAR & & & & & \\
\hline $\begin{array}{l}\text { total energy per ton fresh tea } \\
\text { leaf(MJ) }\end{array}$ & & 807.83 & & & & 1496.38 & & this \\
\hline $\begin{array}{l}\text { total exergy per ton fresh tea } \\
\text { leaf (MJ) }\end{array}$ & & 273.43 & & {$[29]$} & & 821.86 & & \\
\hline
\end{tabular}


In this study, it was considered $40 \mathrm{MJ} / \mathrm{kg}$ energy is utilized for the production of the nitrogenous fertilizer, approaching to the theoretical minimum referring to previous report for the modern factory [31]. Tea plantation in Black Sea region have the same common background with Gamboeng West Java region in agricultural management which are, no irrigation. Tea plantation in Gamboeng had been introduced since the Dutch colonial in Indonesia, therefore energetic and exergetic requirements of the seed consumption are neglected. By using these values, the energy and exergy utilization for black sea fresh tea leaves was calculated to be $807.83 \mathrm{MJ} / \mathrm{t}$ of fresh leaf, $273.43 \mathrm{MJ} / \mathrm{t}$ of fresh leaf, respectively. For the Gamboeng green tea, the energy and exergy utilization were $1496.38 \mathrm{MJ} / \mathrm{t}$ of fresh leaf and $821.86 \mathrm{MJ} / \mathrm{t}$ of fresh leaf, respectively.

\section{Conclusion}

In order to achieve Sustainable Development Goal, many research project had already conducted by Research Center for Chemistry, Indonesian Institute of Science. Small scale electric free furnace for producing activated carbon from peat as water purifier in Borneo [42]. This collaborative research with Hokkaido University was implementing partnership for the goals and conducted for achieving clean water and sanitation for all. The research for developing high quality banana flour production process complete with simple but reliable test kit for quality control was conducted to achieve not just zero hunger but also zero malnutrition since banana flour was very good for baby food [43,44]. In this work Cooperation of wood pellet with ambient-adapting controller was examined as a contribution from Research Center for Chemistry and Gamboeng tea for achieving affordable and clean energy and also an applicable climate action.

Tea plantation in Gamboeng had been introduced since the Dutch colonial in Indonesia, therefore energetic and exergetic requirements of the seed consumption are neglected. By using these values, the energy and exergy utilization for black sea fresh tea leaves was calculated to be $807.83 \mathrm{MJ} / \mathrm{t}$ of fresh leaf, $273.43 \mathrm{MJ} / \mathrm{t}$ of fresh leaf, respectively. For the Gamboeng green tea, the energy and exergy utilization were $1496.38 \mathrm{MJ} / \mathrm{t}$ of fresh leaf and $821.86 \mathrm{MJ} / \mathrm{t}$ of fresh leaf, respectively.

Further analysis about the exergy analysis of the tea factory will be delivered in part.2. The analysis results deliver recommended improvement by installing better humidity detector and connected to the process control so the process can adapt the ambient change which the relative humidity can be varied from $65 \%$ and up to $92 \%$. Reducing $0.01 \mathrm{~kg} \mathrm{LPG}$ per $\mathrm{kg}$ of product means reducing $42.2 \mathrm{~kg}$ of LPG per batch which reduce cost Rp 477.000 per batch.

\section{References}

1. M. Giampietro, S. G. F. Bukkens, and D. Pimentel. Agric. Syst. 45, 19-41 (1994)

2. H. Dalsgard, and L. Munkoe. Int. J. Appl. Thermodyn. 3, 163-170. (2000)

3. S. Kytzia, M. Faist, and P. Baccini. J. Cleaner Prod. 12, 877-889 (2004)

4. M. Braungart, W. McDonough, and A. Bollinger. J. Cleaner Prod. 15, 1337-1348 (2007)

5. P.Roy, D. Nei, T. Orikasa, Q. Xu, H. Okadome, N. Nakamura, and T. Shiina. J. Food Eng. 90, 1-10 (2009)

6. D. Maes, and S. Van Passel. Environ. Impact Assess. Rev. 45, 19-29 (2014)

7. W. VanGool. Energy 5, 783-792. (1980)

8. R.L. Cornelissen, Thermodynamics and Sustainable Development: The Use of Exergy Analysis and the Reduction of Irreversibility (University of Twente, Enschede, 1997) 
9. Z. Rant. Forschung im Ingenieurwesen 22, 1, S.36-37 (1956)

10. C.A. Berg. Energy 5, 733-742 (1980)

11. H.W. Hevert, and S.C. Hevert, Energy 5, 865-873 (1980)

12. I. Dincer, and M.A. Rosen, Chemical exergy. In: Exergy, 2nd ed., Chap. 3, pp. 31-49. Ibrahim, D. and Marc, A.R., Eds. (Elsevier, London, 2013)

13. J. Szargut, Exergy analysis. In: Academia, 3, pp. 31-33. (2005)

14. A. Zvolinschi, S. Kjelstrup, O. Bolland, and H.J. van der Kooi. J. Ind. Ecol. 11, 85-98 (2007)

15. M.A. Rosen, I. Dincer, and M. Kanoglu. Energy Policy 36, 128-137 (2008)

16. E.Sciubba. Termotehnica 1, 11-25 (2009)

17. G. Wall (1988). Energy 13, 197-208

18. I. Dincer, and M.A. Rosen, Applications of exergy in industry. In: Exergy, 2nd ed., Chap. 5, pp. 75-82. Ibrahim, D. and Marc, A. R., Eds. (Elsevier, London, 2013)

19. M. Gong, and G. Wall. Exergy Int. J. 1, 217-233 (2001)

20. I. Dincer, and Y. Cengel. Entropy 3, 116-149 (2001)

21. I. Dincer. En. Policy 30, 137-149 (2002b)

22. F.K. Zisopoulos, F.J. Rossier-Miranda, A.J. van der Goot \& R. M. Boom. Critical Reviews in Food Science and Nutrition 57, 1, 197-211 (2017)

23. A.H. Tambunan, L.P. Manalu, and K. Abdullah. Dry. Technol. 28, 1107-1112 (2010)

24. A. Serpen, E. Pelvan, C. Alasalvar, B.A. Mogol, H.T. Yavuz, V. Gökmen, N. Özcan, B. Özçelik. J. Agric. Food. Chem. 60, 7682-7689 (2012)

25. C. Alasalvar, B. Topal, A. Serpen, M. Bahar, E. Pelvan, V. Gökmen, J. Agric. Food. Chem., 60, 6323-6332 (2012)

26. J. Szargut, D.R. Morris, F.R. Steward, Exergy Analysis of Thermal, Chemical and Metallurgical Processes (Hemisphere Publishing Corporation, New York, 1988)

27. L. Shao, G.Q. Chen, Ecol. Indic. 58, 392-401 (2015)

28. M.E. Harbowy, D.A. Balentine. Crit. Rev. Plant Sci. 16, 415-480 (1997)

29. E. Pelvan, M. Özilgen. Sustainable Production and Consumption 12, 59-77 (2017)

30. E. Sorgüven, M.Özilgen. Energy 32, 1956-1966 (2010)

31. A. Anundskas, Technical improvements in mineral nitrogen fertilizer production. In: Harvesting energy with fertilizers (European Fertilizer Man. Assoc., 2000)

32. Z.R. Helsel, Energy and alternatives for fertilizer and pesticide use. In: Fluck, R.C. (Ed.), Energy in Farm Production (Elsevier, New York, 1992)

33. H. Wittmus, L. Olson, D. Lane. J. Soil Water Conserv. 3, 72-75 (1975)

34. D. Pimentel. J. Agric. Environ. Ethics 4, 1-13 (1991)

35. N. Banaeian, M. Omid, H. Ahmadi. Energy Convers. Manage. 5, 1020-1025 (2011)

36. T.H. Jayah, Evaluation of a downdraft wood gasifier for tea manufacturing in Sri Lanka (The University of Melbourne, 2002).

37. B.P. Baruah, P. Khare, P.G. Rao. Two Bud 59, 9-13 (2012)

38. Asian Institute of Technology Small and Medium Scale Industries in Asia: Energy and Environment, Tea Sector.

http://faculty.ait.ac.th/visu/public/uploads/books/SMSIAEETS.pdf (2002).

39. W.C.A. de Silva. Sri Lanka J. Tea Sci. 63, 59-69 (1994)

40. M. Özilgen, E. Sorgüven, Energy 36, 5954-5967 (2011)

41. B.E. Saraç. Int. J. Exergy 18, 323-339 (2015) 